\title{
Response to 'Plasma proteins present in osteoarthritic synovial fluid can stimulate cytokine production via Toll-like receptor 4' - authors' reply
}

\author{
Dong Hyun Sohn+1,2, Jeremy Sokolove ${ }^{\dagger 1,2}$, Orr Sharpe ${ }^{\dagger 1,2}$, Jennifer C Erhart ${ }^{3,4}$, Piyanka E Chandra ${ }^{1,2}$, Lauren J Lahey L $^{1,2}$, \\ Tamsin M Lindstrom, ${ }^{1,2}$, Inyong Hwang ${ }^{1,2}$, Katherine A Boyer ${ }^{3,4}$, Thomas P Andriacchi3,4 and William H Robinson*1,2 \\ See related research by Sohn et al., http://arthritis-research.com/content/14/1/R7, and related letter by Oliviero et al., \\ http://arthritis-research.com/content/14/5/405
}

We thank Oliviero and colleagues for their interest in our recent publication [1] and for reporting their very interesting related experiments [2]. Their results strongly support the concept that extravascular plasma proteins may act as damage-associated molecular patterns, and specifically as Toll-like receptor 4 agonists. In addition, we note that the NALP-3 inflammasome exhibits dependence on Toll-like receptor 4 or other mechanisms of priming of IL- $1 \beta$ transcription, thereby generating pro-IL- $1 \beta$ that can be converted to IL- $1 \beta$ by the activated inflammasome [3].

Although biochemical measurement of plasma and serum were not performed, we suspect the enhanced effect of serum compared with plasma could be related to mediators generated in the clotting process or released by platelets during the clotting process (but not released in the generation of plasma) and not related to the removal of fibrinogen. The observation that fibrinogen is itself able to prime the response to calcium crystalinduced inflammation further supports the role of fibrinogen as a Toll-like receptor 4 agonist [4,5], as demonstrated by its ability to prime the inflammasome for response to activation by calcium crystals.

We thank Oliviero and colleagues for sharing their results and look forward to future studies elucidating the potentially critical role of plasma proteins as extravascular damage-associated molecular patterns.

${ }^{+}$Contributed equally.

*Correspondence: wrobins@stanford.edu

'GRECC, VA Palo Alto Health Care System, MC 154R, 3801 Miranda Avenue, Palo

Alto, CA 94304, USA

Full list of author information is available at the end of the article

\section{Abbreviations}

IL, interleukin.

\section{Competing interests}

The authors declare that they have no competing interests.

\section{Author details}

'GRECC, VA Palo Alto Health Care System, MC 154R, 3801 Miranda Avenue Palo Alto, CA 94304, USA. 2Division of Immunology and Rheumatology, Department of Medicine, Stanford University School of Medicine, Stanford, CA 94305, USA. ${ }^{3}$ Bone and Joint Center, VA Palo Alto Health Care System, 3801 Miranda Avenue, Palo Alto, CA 94304, USA. ${ }^{4}$ Department of Mechanical Engineering, Stanford University, Stanford, CA 94305, USA.

\section{Published: 12 September 2012}

\section{References}

1. Sohn DH, Sokolove J, Sharpe O, Erhart JC, Chandra PE, Lahey LJ, Lindstrom TM, Hwang I, Boyer KA, Andriacchi TP, Robinson WH: Plasma proteins present in osteoarthritic synovial fluid can stimulate cytokine production via Toll-like receptor 4. Arthritis Res Ther 2012, 14:R7.

2. Oliviero F, Scanu A, Dayer J-M, Fiocco U, Sfriso P, Punzi L: Response to 'Plasma proteins present in osteoarthritic synovial fluid can stimulate cytokine production via Toll-like receptor 4'. Arthritis Res Ther 2012, 14:405.

3. Martinon F, Petrilli V, Mayor A, Tardivel A, Tschopp J: Gout-associated uric acid crystals activate the NALP3 inflammasome. Nature 2006, 440:237-241.

4. Smiley ST, King JA, Hancock WW: Fibrinogen stimulates macrophage chemokine secretion through Toll-like receptor 4. J Immunol 2001, 167:2887-2894.

5. Sokolove J, Zhao X, Chandra PE, Robinson WH: Immune complexes containing citrullinated fibrinogen costimulate macrophages via Toll-like receptor 4 and Fcy receptor. Arthritis Rheum 2011, 63:53-62.

doi:10.1186/ar3892

Cite this article as: Sohn DH, et al:: Response to 'Plasma proteins present in osteoarthritic synovial fluid can stimulate cytokine production via Toll-like receptor 4' - authors' reply. Arthritis Research \& Therapy 2012, 14:406. 